\title{
Distribution of crystals in the superficial zone of elderly human articular cartilage of the femoral head in subcapital fracture
}

Department of Anatomy, University Medical School, Teviot Place, R A Stockwell

Correspondence to: Professor Stockwell. Accepted for publication 6 June 1989

\begin{abstract}
Crystal distribution in articular cartilage of femoral heads resected at hip arthroplasty for fracture of the femoral neck was examined in 10 patients (77-91 years) by computerised image analysis of electron micrographs. Crystal content of the zenith did not differ from that of the infrafoveal region of the femoral head in the superficial $0.5 \mathrm{~mm}$ of the cartilage. Crystal area density (percentage area of the section occupied by crystal profiles) was higher in a zone $0-50 \mu \mathrm{m}$ than in the subjacent zone $50-500 \mu \mathrm{m}$ from the articular surface, particularly in the zenith of the femoral head. It was also higher on the superficial (towards the articular surface) aspect than on the deep aspect of cells in perilacunar matrix. Crystal area density was similar in lacunar matrix, perilacunar matrix, and matrix remote from cells. Matrix containing cell debris was more heavily impregnated with crystals than any other site. No difference in crystal content was observed in cartilage beneath articular surfaces which were ultrastructurally smooth or roughened. The diminishing gradient of crystal area density with depth from the articular surface, the absence of a marked spatial association with living cells, and the impregnation of sites containing cell debris suggest that crystal deposition in these cases is not due primarily to chondrocyte activity.
\end{abstract}

Although articular cartilage is bonded to the subchondral bone by a basal layer of calcified cartilage, crystals are not usually found in its main non-calcified layer. Various types of mineral, including calcium pyrophosphate dihydrate and calcium phosphate (apatite) cuboidal crystals, are deposited in crystal deposition diseases. ${ }^{1}$ Cuboidal and other crystals also occur in osteoarthritic cartilage. ${ }^{2}{ }^{3}$ In the elderly a zone of mineralisation in the articular cartilage may be seen on radiography of apparently normal joints and becomes more common after the age of $75 .^{4}$ Owing to their electron density, such cuboid crystals are easily seen on electron microscopy of the joint cartilage. In femoral heads resected at hip arthroplasty for fracture of the femoral neck electron microscopy has shown that cuboid crystals are located almost exclusively in the superficial zone of the structurally normal cartilage. ${ }^{5}$ It is not known whether these crystals occur primarily owing to changes in the cartilage matrix or in chondrocyte activity or to causes external to the cartilage. To investigate this problem further the distribution of such cuboid crystals within the superficial zone of femoral head articular cartilage was assessed quantitatively by automated image analysis of electron micrographs.

\section{Materials and methods}

Articular cartilage was obtained from femoral heads of 10 patients (77-91 years; eight female, two male) with fracture of the neck of the femur treated by hip arthroplasty. The time between fracture and surgery varied, but in six cases was within 24 hours. Cartilage surfaces in general were macroscopically smooth, though there was minimal roughening and fissuring as seen by electron microscopy in the region below the fovea in five cases.

Four tissue blocks were taken from each of two sites: the superior surface (or zenith) and the inferior surface (infrafoveal). They were fixed in 5\% glutaraldehyde, and tissue for quantitative analysis was processed for electron microscopy without postfixation in osmium tetroxide or further section staining. One block was selected at random from each site and sections $0.3 \mu \mathrm{m}$ thick were cut normal to the articular surface, mounted on copper grids, and examined in a Philips 301 transmission electron microscope at $60 \mathrm{kV}$.

Electron micrographs (magnification $\times 7500$ ) were taken of matrix $(a)$ in a zone $0-50 \mu \mathrm{m}$ and (b) in a zone $50-500 \mu \mathrm{m}$ from the articular surface. Within these two zones five sites were photographed: (a) matrix remote-that is, lying 30-50 $\mu \mathrm{m}$ from cells; (b) perilacunar matrix (external to the cell lacuna) within $10 \mu \mathrm{m}$ of normal cells: (i) on the superficial aspects (towards the articular surface) of the cell, (ii) on the deep aspect of the cell; $(c)$ lacunar matrix around normal cells; $(d)$ matrix which included degenerate cells or cell debris.

A form of systematic random sampling was used such that photomicrographs were taken of regions of the thin section on a constant side of sequential grid squares. Two separate squares each of area equivalent to $25 \mu \mathrm{m}^{2}$ in each micrograph were examined for crystal content by a Magiscan 2A (Joyce-Loebl, Gateshead, UK) image analyser. In each of the sites listed above the analyser was programmed to measure: (a) the mean area of individual crystal profiles; (b) the mean maximum length and the mean maximum breadth of individual crystal profiles; (c) the number of crystal profiles per $25 \mu \mathrm{m}^{2}$ of section; $(d)$ the percentage area of tissue section occupied by crystal profiles (area density).

Readings over parts of the sections containing araldite embedding medium only-that is, surrounding the cartilage tissue-were also taken. 
Figure 1: Superficial zone of articular cartilage of femoral head (woman aged 82 years) after subcapital fracture. Electron micrograph of stained section: $S=$ articular surface; arrows indicate cuboidal crystals. Bar $=1 \mu \mathrm{m}$.
Figure 2: High magnification of one of the crystals indicated in fig 1 . Note the membrane-like structure (arrow) around the crystal. $\mathrm{Bar}=0 \cdot 1 \mu \mathrm{m}$.
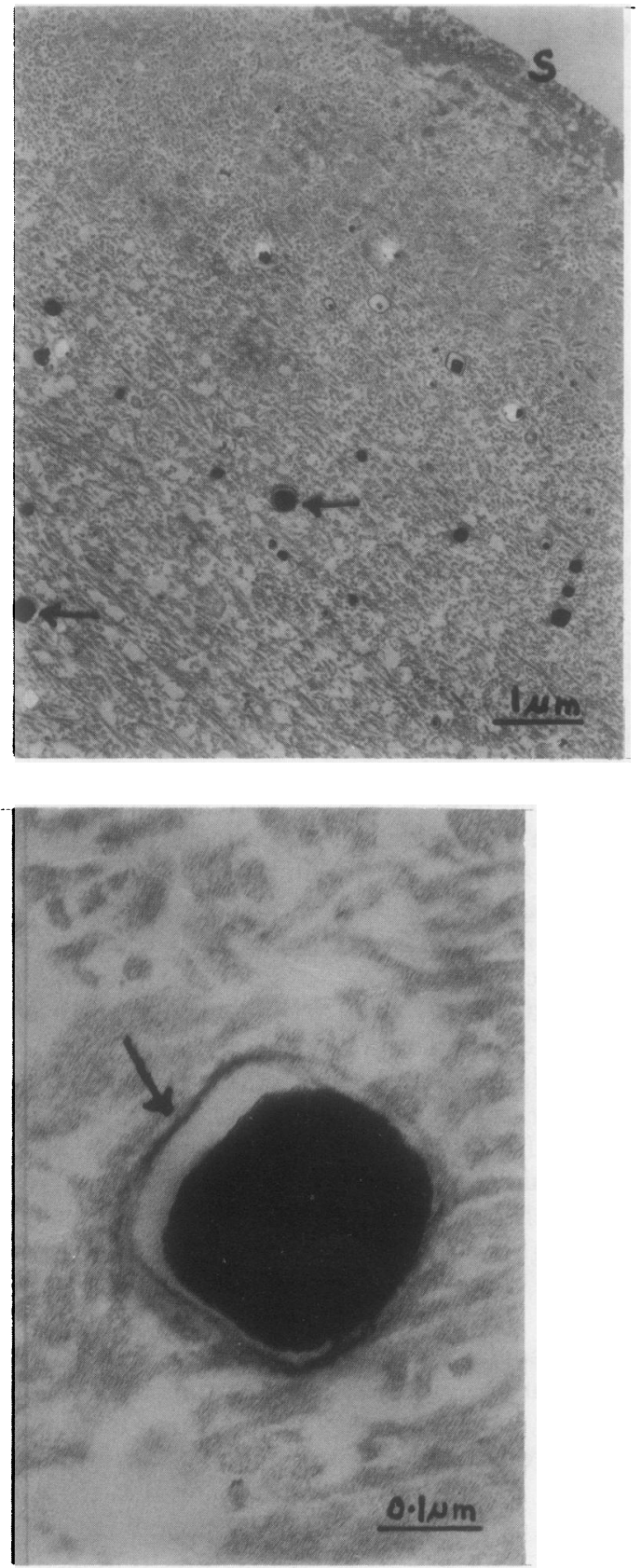

Some sections were examined and photographed after conventional staining with uranyl acetate and lead citrate.

\section{Results}

The tissue blocks for microscopy included about $1.5 \mathrm{~mm}$ of the full cartilage thickness. A preliminary survey showed that crystals were rarely seen, if ever, in matrix lying more than $0.5 \mathrm{~mm}$ from the articular surface. Hence the quantitative study was confined to the superficial $0.5 \mathrm{~mm}$ of the cartilage.

Within the superficial cartilage, crystals were present in all cases examined, though they were not invariably present in all five sites of the matrix. They had a high contrast electron density (figs 1 and 2). Readings taken over parts of the section containing araldite embedding resin only were always negative. This indicated that artefacts due to displacement of crystals during tissue preparation or to electron dense contaminating material were minimal or negligible.

Crystal profiles ranged in area from 0.001 to $0.2 \mu \mathrm{m}^{2}$. Mean crystal areas (table 1) were in general similar in the different zones and sites examined, except where specifically indicated below. Ratios of mean length to mean breadth ranged from 1.05 to 1.23 (table 2) and, except in the region of cell debris, no significant differences were observed between the various sites examined.

\section{MATRIX REMOTE FROM CELLS}

In the superficial $0.5 \mathrm{~mm}$-that is, $0-50$ and 50-500 $\mu \mathrm{m}$ zones combined-of the cartilage the crystal content of the zenith did not differ from that of the infrafoveal region, either in numbers of crystals per $25 \mu \mathrm{m}^{2}$ (zenith 0.44 (SEM $0 \cdot 15)$; infrafoveal $0.68(0.330))$ or in crystal area density (zenith $0.026(0.008)$; infrafoveal $0.037(0.022))$.

Crystal number (table 3) and crystal area density (table 4) were higher in the $50 \mu \mathrm{m}$ zone

Table 1: Mean (SEM) area $\left(\mu m^{2}\right)$ of crystals in different matrix sites

\begin{tabular}{|c|c|c|c|c|}
\hline & \multirow{2}{*}{$\begin{array}{l}\text { Remote } \\
\text { matrix }\end{array}$} & \multicolumn{2}{|l|}{ Perilacunar matrix } & \multirow{2}{*}{$\begin{array}{l}\text { Lacunar } \\
\text { matrix }\end{array}$} \\
\hline & & Superficial & Deep & \\
\hline $\begin{array}{l}\text { Zenith } \\
0-50 \mu \mathrm{m} \\
50-500 \mu \mathrm{m}\end{array}$ & $\begin{array}{l}0.013(0.0019) \\
0.021(0.0055)^{*}\end{array}$ & $\begin{array}{l}0.013(0.0018) \\
0.0097(0.0017)^{*}\end{array}$ & $\begin{array}{l}0.014(0.0028) \\
0.011(0.00082)\end{array}$ & $\begin{array}{l}0.0095(0.0030) \\
0.0096(0.0011)\end{array}$ \\
\hline $\begin{array}{l}\text { Infrafoveal } \\
0-50 \mu \mathrm{m} \\
50-500 \mu \mathrm{m}\end{array}$ & $\begin{array}{l}0.011(0.00096) \\
0.015(0.0030)\end{array}$ & $\begin{array}{ll}0.012 & (0.0016) \\
0.015 & (0.0026)\end{array}$ & $\begin{array}{l}0.011(0.00077) \\
0.012(0.0021)\end{array}$ & $\begin{array}{ll}0.015 & (0.0040) \\
0.010 & (0.0031)\end{array}$ \\
\hline
\end{tabular}

${ }^{*} \mathrm{t}=2 \cdot 19, \mathrm{p}<0 \cdot 05$.

Table 2: Ratios of maximum length: maximum breadth of crystals in different matrix sites. Values are means (SEM)

\begin{tabular}{|c|c|c|c|c|}
\hline & \multirow{2}{*}{$\begin{array}{l}\text { Remote } \\
\text { matrix }\end{array}$} & \multicolumn{2}{|c|}{ Perilacunar matrix } & \multirow{2}{*}{$\begin{array}{l}\text { Lacunar } \\
\text { matrix }\end{array}$} \\
\hline & & Superficial & Deep & \\
\hline $\begin{array}{l}\text { Zenith } \\
0-50 \mu \mathrm{m} \\
50-500 \mu \mathrm{m}\end{array}$ & $\begin{array}{l}1 \cdot 10(0.019) \\
1 \cdot 12(0.030)\end{array}$ & $\begin{array}{l}1.07(0.021) \\
1.15(0.040)\end{array}$ & $\begin{array}{l}1 \cdot 14(0.066) \\
1 \cdot 15(0.077)\end{array}$ & $\begin{array}{l}1 \cdot 12(0.028) \\
1 \cdot 14(0.040)\end{array}$ \\
\hline $\begin{array}{c}\text { Infrafoveal } \\
0-50 \mu \mathrm{m} \\
50-500 \mu \mathrm{m}\end{array}$ & $\begin{array}{l}1.13(0.020) \\
1.09(0.017)\end{array}$ & $\begin{array}{l}1 \cdot 12(0.033) \\
1 \cdot 12(0.022)\end{array}$ & $\begin{array}{l}1.05(0.18) \\
1 \cdot 14(0.052)\end{array}$ & $\begin{array}{l}1.08(0.017) \\
1.23(0.154)\end{array}$ \\
\hline
\end{tabular}


Table 3: Mean number of crystals per $25 \mu^{2}$ in different matrix sites. Values are means (SEM)

\begin{tabular}{|c|c|c|c|c|}
\hline & \multirow{2}{*}{$\begin{array}{l}\text { Remote } \\
\text { matrix }\end{array}$} & \multicolumn{2}{|l|}{ Perilacunar matrix } & \multirow{2}{*}{$\begin{array}{l}\text { Lacunar } \\
\text { matrix }\end{array}$} \\
\hline & & Superficial & Deep & \\
\hline $\begin{array}{l}\text { Zenith } \\
0-50 \mu \mathrm{m} \\
50-500 \mu \mathrm{m}\end{array}$ & $\begin{array}{l}2.65(0.94) \\
0.19(0.08)^{* * *} \\
(\mathrm{t}=2 \cdot 60, \mathrm{p}<0.05)\end{array}$ & $\begin{array}{l}1.08(0.49)^{*} \\
0.35(0 \cdot 11)^{* *} \\
(t=2 \cdot 88, p<0.01)\end{array}$ & $\begin{array}{l}0.40(0.15)^{*} \\
0.06(0.04)^{*} \\
(\mathrm{t}=2 \cdot 19, \mathrm{p}<0.05)\end{array}$ & $\begin{array}{l}2.65(0.99) \\
0.92(0.24)^{* * *}\end{array}$ \\
\hline $\begin{array}{c}\text { Infrafoveal } \\
0-50 \mu \mathrm{m} \\
50-500 \mu \mathrm{m}\end{array}$ & $\begin{array}{l}2.04(0.90) \\
0.52(0.27)\end{array}$ & $\begin{array}{l}4.73(2.27) \\
0.87(0.38)\end{array}$ & $\begin{array}{l}2.40(1.58) \\
0.59(0.34)\end{array}$ & $\begin{array}{l}1.97(0.98) \\
1.40(0.6)\end{array}$ \\
\hline
\end{tabular}

${ }^{*} \mathrm{t}=2 \cdot 74, \mathrm{p}<0.05 ;{ }^{* *} \mathrm{t}=2.39, \mathrm{p}<0.05 ;{ }^{* * * *} \mathrm{t}=2.94, \mathrm{p}<0.01$.

Table 4: Area density of crystals (percentage area of section occupied by crystal profiles) in different matrix sites. Values are means (SEM)

\begin{tabular}{|c|c|c|c|c|}
\hline & \multirow{2}{*}{$\begin{array}{l}\text { Remote } \\
\text { matrix }\end{array}$} & \multicolumn{2}{|l|}{ Perilacunar matrix } & \multirow{2}{*}{$\begin{array}{l}\text { Lacunar } \\
\text { matrix }\end{array}$} \\
\hline & & Superficial & Deep & \\
\hline $\begin{array}{c}\text { Zenith infrafo } \\
0-50 \mu \mathrm{m} \\
50-500 \mu \mathrm{m}\end{array}$ & $\begin{array}{l}\text { combined } \\
0.11(0.028) \\
0.023(0.01) \\
(\mathrm{t}=2.87, \mathrm{p}<0.05)\end{array}$ & $\begin{array}{ll}0.12 & (0.046) \\
0.03 & (0.008)^{*}\end{array}$ & $\begin{array}{ll}0.043 & (0.02) \\
0.009 & (0.005)^{*}\end{array}$ & $\begin{array}{l}0.13(0.066) \\
0.045(0.014)\end{array}$ \\
\hline $\begin{array}{l}\text { Zenith } \\
0-50 \mu \mathrm{m} \\
50-500 \mu \mathrm{m}\end{array}$ & $\begin{array}{l}0.13(0.047) \\
0.015(0.006) \\
(t=2.36, p<0.05)\end{array}$ & $\begin{array}{l}0.08(0.021)^{* *} \\
0.018(0.005)^{* * *} \\
(\mathrm{t}=2.82, \mathrm{p}<0.05)\end{array}$ & $\begin{array}{l}0.022(0.009)^{* *} \\
0.0021(0.002)^{* * *} \\
(\mathrm{t}=2 \cdot 10, \mathrm{p}<0.05)\end{array}$ & $\begin{array}{l}0.15(0.079) \\
0.042(0.011)\end{array}$ \\
\hline $\begin{array}{c}\text { Infrafoveal } \\
0-50 \mu \mathrm{m} \\
50-500 \mu \mathrm{m}\end{array}$ & $\begin{array}{ll}0.10 & (0.044) \\
0.03 & (0.02)\end{array}$ & $\begin{array}{ll}0.16 & (0.083) \\
0.04 & (0.016)\end{array}$ & $\begin{array}{l}0.07(0.04) \\
0.016(0.009)\end{array}$ & $\begin{array}{l}0.11 \quad(0.057) \\
0.049(0.022)\end{array}$ \\
\hline
\end{tabular}

near the articular surface than in the deeper (50-500 $\mu \mathrm{m})$ zone. The greater crystal deposition in the most superficial cartilage was more significant at the zenith than in the infrafoveal region. Mean areas of crystals tended to be higher in the more superficial zone, but the difference from the deeper zone was not significant.

PERILACUNAR MATRIX NEAR NORMAL CELLS Crystal number and area density (tables 3 and 4) showed a similar trend in this site to that in the remote matrix. Within $50 \mu \mathrm{m}$ of the articular surface the matrix tended to be more heavily impregnated with crystals than in the deeper

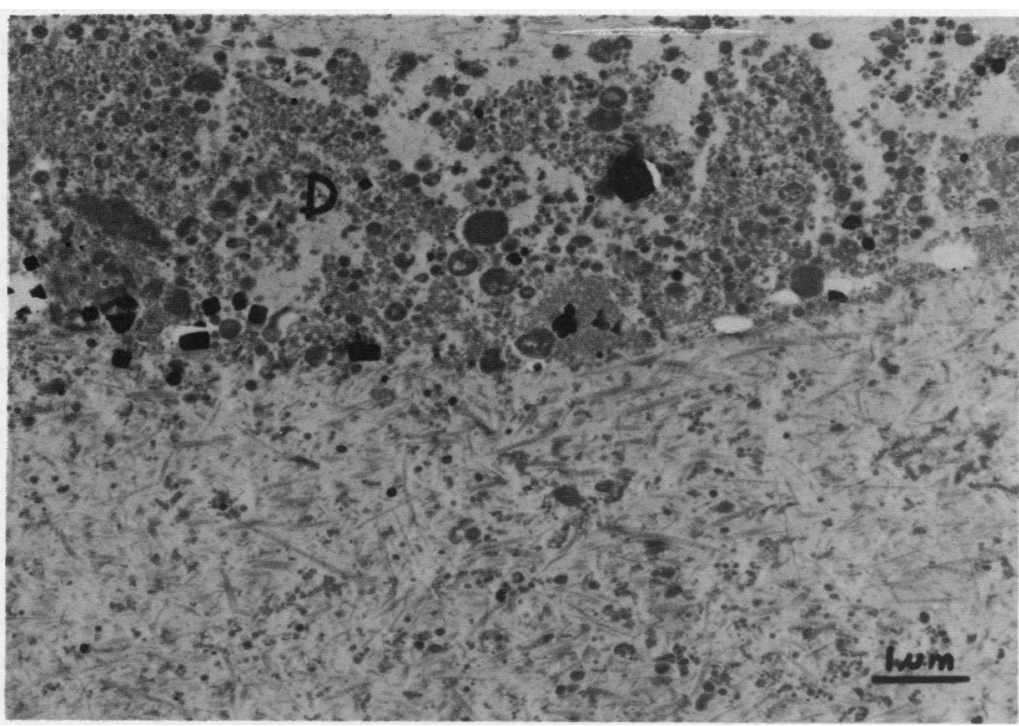

Figure 3: Crystals overlying cell debris (D). Bar $=1 \mu \mathrm{m}$. zone, particularly at the zenith. On the superfical side of the cells perilacunar matrix showed higher crystal numbers and area densities than on the deep side of the cells; this was significantly so in the zenith. Crystal area density in perilacunar matrix was similar to that in remote matrix within the same zone. Crystal size (table 1) was slightly lower in perilacunar matrix than in remote matrix of the zenith cartilage.

\section{LACUNAR MATRIX AROUND NORMAL CELLS}

As in most adult cartilages, this site often contained lipid vesicles and particles. They had a much lower electron density than the crystals and were easily distinguished from them by the image analyser. Crystal area density and number again showed a superficial/deep zone preponderance (tables 3 and 4 ) as seen in remote matrix and perilacunar matrix. In both zones, however, there were few significant differences in crystal number or area density from values obtained for matrix remote from cells or from perilacunar matrix. Exceptionally, in the deeper zone $50-500 \mu \mathrm{m}$ from the articular surface of the zenith, crystal number was significantly higher in lacunar matrix than in remote matrix; there was no such difference in area density.

No crystals were observed intracellularly.

\section{MATRIX CONTAINING CELL DEBRIS AND}

\section{DEGENERATE CELLS}

In general this site was more heavily impregnated with crystals than any other part of the matrix (fig 3), as shown by both crystal number and area density. When values for individual areas of cell debris were compared with those for individual normal cell lacunae the crystal area density was much higher $(t=11.59, p<0.001)$ 
Table 5: Area density of crystals (percentage area of section occupied by crystal profiles) in cartilage beneath normal smooth surfaces and roughened surfaces in the infrafoveal region of the femoral head. Values are means (SEM)

\begin{tabular}{|c|c|c|c|c|}
\hline & \multirow{2}{*}{$\begin{array}{l}\text { Remote } \\
\text { matrix }\end{array}$} & \multicolumn{2}{|c|}{ Perilacunar matrix } & \multirow{2}{*}{$\begin{array}{l}\text { Lacunar } \\
\text { matrix }\end{array}$} \\
\hline & & Superficial & Deep & \\
\hline $\begin{array}{l}0-50 \mu \mathrm{m} \\
\text { Normal } \\
\text { Roughened }\end{array}$ & $\begin{array}{ll}0.14 & (0.087) \\
0.052 & (0.014)^{*}\end{array}$ & $\begin{array}{l}0.22(0.17) \\
0.098(0.034)\end{array}$ & $\begin{array}{l}0.081(0.079) \\
0.059(0.030)\end{array}$ & $\begin{array}{l}0.075(0.039) \\
0.15(0.11)\end{array}$ \\
\hline $\begin{array}{l}50-500 \mu \mathrm{m} \\
\text { Normal } \\
\text { Roughened }\end{array}$ & $\begin{array}{l}0.051(0.042) \\
0.0095(0.011)^{*}\end{array}$ & $\begin{array}{l}0.027(0.020) \\
0.058(0.014)\end{array}$ & $\begin{array}{l}0.007(0.002) \\
0.025(0.018)\end{array}$ & $\begin{array}{l}0.052(0.032) \\
0.045(0.034)\end{array}$ \\
\hline
\end{tabular}

${ }^{*} t=2 \cdot 85, p<0 \cdot 05$

for cell debris $(0.70($ SEM 0.084$), \mathrm{n}=25)$ than for normal lacunae $(0.08(0.016), n=106)$. Crystal size was also slightly higher $(t=2 \cdot 18$; $\mathrm{p}<0.05)$ in regions of cell debris $(0.02(0.0027$ $\mu \mathrm{m})$ than in normal lacunae $(0.012(0.0018)$ $\mu \mathrm{m})$.

\section{CARTILAGES WITH ABNORMAL ARTICULAR SURFACES}

Cases in which electron microscopy showed surface roughening in the infrafoveal region were compared with those with normal infrafoveal surfaces. The number of cases in each group was small (five) and no significant differences in crystal area density were detected in the various matrix sites. In matrix remote from cells, however, area density tended to be less in cases with roughened surfaces than in normal cases, while in matrix near cells there was no consistent trend (table 5).

\section{Discussion}

In cartilage, crystal form can vary enormously, ${ }^{6}$ but the results of the shape analysis presented here, showing a mean length/breath ratio close to unity, suggest cuboidal, circular, or irregular forms rather than needle shaped crystals. This gives little information about the chemical nature of the crystals but gives some support to earlier qualitative observations of the cuboidal shape of many of the crystals seen in elderly non-fibrillated and osteoarthritic human articular cartilage. In previous studies using $x$ ray emission microanalysis elemental ratios of calcium and phosphorus indicated that the cuboidal crystals are of an apatite nature in femoral head cartilages from subcapital fractures, ${ }^{5}$ though owing to their content of magnesium they may be of the closely related whitlockite type in fibrillated cartilage. ${ }^{2}$

The results for crystal profile numbers and for crystal area density show a similar pattern. It is, however, known to be difficult to estimate the absolute number of objects within an area or volume of tissue for various technical reasons. ${ }^{7}$ Morphometrically, estimates of area densitythat is, total area of object profiles in the plane of the tissue section-are both simpler to obtain and more reliable. More weight, therefore, can be given to the results for crystal area density than to crystal number. Area density also has the advantage that, numerically, it is equivalent to volume density ${ }^{7}$ - that is, the volume of crystals per unit volume of cartilage matrix. Hence, although crystal deposition was quite variable between cases, certain general comments can be made on the basis of the results for crystal area density.

Firstly, the quantitative evidence in this study shows that there are no especially high densities of crystal deposition in pericellular sites, as suggested earlier both in elderly cartilage from patients with fractured neck of femur ${ }^{5}$ and in fibrillated cartilage. ${ }^{3}$ It has been shown both by light ${ }^{9}$ and electron microscopy, ${ }^{10}$ however, that in calcium pyrophosphate dihydrate the earliest deposits in articular cartilage occur close to the cells. In the case of the elderly cartilage examined here, it seems that lacunar and perilacunar matrix around normal cells has no greater crystal content than matrix remote from cells. On the deep aspect of the chondrocytes, crystal deposition is less than elsewhere. Hence this study offers no support for a positive role of living chondrocytes in the crystal deposition seen in superficial cartilage in cases of fractured neck of femur, though this has been suggested for pyrophosphate deposition in calcium pyrophosphate dihydrate. ${ }^{11}$ On the other hand, the high crystal deposition in areas of cell debris suggests that the chemical nature of the debris or changes in the matrix induced by cell death or loss of cell activity may be the factors responsible.

Secondly, crystal deposition near (0-50 $\mu \mathrm{m})$ the articular surface was more profuse than in deeper tissue $(50-500 \mu \mathrm{m})$ whether in matrix remote from or near to cells. This suggests an extra-articular source for the precursors required for crystal formation, entering via the articular surface. This might be related to the osteoporosis commonly seen in cases of fractured neck of femur. Although serum calcium and phosphorus concentrations are normal in osteoporosis, they tend to be at the upper end of the normal range. ${ }^{12}$ The comparative immobility of elderly patients might also have made a contribution through accelerated bone resorption. Even in hyperparathyroidism, however, the incidence of chondrocalcinosis does not correlate with serum calcium concentrations, ${ }^{4}$ and it is known that the ionic concentrations of calcium and phosphate in cartilage are normally supersaturated. ${ }^{13}$

This suggests that factors internal to the tissue are indeed necessary. In epiphyseal growth cartilage small membranous 'matrix vesicles' are known to have a role in mineralisation. ${ }^{14}$ Such electron dense material in the form of particles and vesicles is commonly seen in or near the lacunae of adult articular chondrocytes and spread more diffusely in the superficial matrix beneath the articular surface. ${ }^{15}$ Although many 
of the cuboidal crystals in this study seem to be enclosed in a membrane-like structure, crystal deposition is not increased in pericellular matrix near normal cells. Nor indeed are crystals in calcium pyrophosphate dihydrate related to matrix vesicles in articular cartilage. ${ }^{16}$ In addition, the lipid material in the superficial zone accumulates early in life, for a long period before mineralisation can be observed. ${ }^{17}$ Hence, in articular cartilage, lipid vesicles may have only a passive role and other factors permissive to mineralisation may be required.

A possible synergistic factor may be the proteoglycans of the matrix. In the superficial zone the concentration of proteoglycans is normally much lower than in the deeper tissue. ${ }^{18} 19$ This zone is also one of the earliest sites of loss of proteoglycan ('regressive change') ${ }^{20}$ or of increased hydration ${ }^{21}$ in cartilage degeneration. If proteoglycan loss were due to molecular degradation, rather than to elution from the matrix, calcium ions bound to those molecules would be released and might serve to enhance crystal formation. Thus early degenerative change might produce the required conditions for mineralisation. It would also be compatible with the presence of the cuboidal crystals ${ }^{8}$ and other apatite crystals found near the surface of fibrillated arthritic cartilage. In this investigation mildly roughened surfacesusually associated with proteoglycan losscontained no more crystals than smooth surfaces, if anything rather less. It has been shown by others, however, that cartilage of the femoral head from cases of subcapital fracture has a significantly reduced content of proteoglycan, ${ }^{22}$ an appreciable loss occurring in the superficial zone. Hence it might be postulated that formation of cuboidal crystals near a nonfibrillated articular surface may occur when three conditions are fulfilled: $(a)$ presence of matrix vesicle-like structures, $(b)$ reduced proteoglycan concentration in the matrix, and (c) an extra-articular source of calcium and phosphate ions. I am most grateful to the orthopaedic surgery staff, Royal Infirmary of Edinburgh, for providing resected surgical speci-
mens and to Professor G Nuki for helpful discussions. I would like to thank Mr R McDougall for skilled preparation of the material for electron microscopy and Miss Helen Dingwall for secretarial assistance. The Magiscan image analyser was purchased with a generous grant from the Wellcome Trust.

1 Dieppe P. New knowledge of chondrocalcinosis. Fournal of Clinical Pathology 1978; 31 (suppl): 214-22.

2 Ali S Y, Griffiths S. Matrix vesicles and apatite deposition in osteoarthritis. In: Ascenzi A, Bonucci E, de Bernard B, eds Matrix vesicles. Milan: Wichtig Editore, 1981: 241-7.

3 Ohira T, Ishikawa K. Hydroxyapatite deposition in osteoarthritic articular cartilage of the proximal femoral head. Arthritis Rheum 1987; 30: 651-60.

4 Pritchard M H, Jessop $D$. Chondrocalcinosis in primary hyperparathyroidism. Ann Rheum Dis 1977; 36: 146-51.

5 de Marante I, Macdougall $R$, Ross A, Stockwell $R$ A. Ultrastructural observations of crystals in articular cartilage of aged human hip joints. Ann Rheum Dis 1983; 42 (suppl 1): $96-7$

6 Dieppe P, Doherty M, Macfarlane D. Crystal-related arthropathies. Ann Rherum Dis 1983; 42 (suppl 1): 1-3

7 Aherne W A, Dunnill M S. Morphometry. London: Arnold, 1982: $60-74$

8 Ali S Y. Crystal induced arthropathy. In: Verbruggen G, Veys E M, eds. Degenerative joints. Vol 2. Amsterdam: Elsevier, 1985: 357-68.

9 McCarty D J. Calcium pyrophosphate dihydrate crystal deposition disease-1975. Arthritis Rheum 1976; 19: 275-85.

10 Pritzker K P H, Cheng P-T, Renlund R C. Calcium pyrophosphate crystal deposition in hyaline cartilage. Ultrastructural analysis and implications for pathogenesis. F Rheumatol 1988; 15: 828-35.

11 Caswell A, Guillard-Cumming D F, Hearn P R, McGuire M K B, Russell R G G. Pathogenesis of chondrocalcinosis and pseudogout. Metabolism of inorganic pyrophosphate and production of calcium pyrophosphate dihydrate crystals. Ann Rheum Dis 1983; 42 (suppl 1): 27-37.

12 Aitken J M. The prevention of osteoporosis. In: Heath D A Marx S J, eds. Calcium disorders. London: Butterworth, 1982: 47-68.

13 Maroudas A. Physicochemical properties of articular cartilage. In: Freeman M A R, ed. Adult articular cartilage. 2nd ed. Tunbridge Wells: Pitman Medical, 1979: 215-90.

14 Bonucci E. Fine structure of early cartilage calcification. f Ultrastruct Res 1967; 20: 33-50.

15 Meachim G, Stockwell R A. The matrix. In: Freeman M A R, ed. Adult articular cartilage. 2nd ed. Tunbridge Wells: Pitman Medical, 1979: 1-67.

16 Schumacher H R. Ultrastructural findings in chondrocalcinosis and pseudogout. Arthritis Rheum 1976; 19: 413-25.

17 Stockwell R A. Biology of cartilage cells. Cambridge: Cam bridge University Press, 1979.

18 Stockwell R A, Scott J E. Distribution of acid glycosaminoglycans in human articular cartilage. Nature 1967; 215: 1316-7.

19 Venn M, Maroudas A. Chemical composition and swelling of normal and osteoarthrotic femoral head cartilage. I. Cheminormal and osteoarthrotic femoral head cartilage. I.

20 Meachim G, Ghadially F N, Collins D H. Regressive changes in the superficial layer of human articula cartilage. Ann Rheum Dis 1965; 24: 23-30.

21 Muir $H$. Current and future trends in articular cartilage research and osteoarthritis. In: Kuettner $\mathrm{KE}$, Schleyerbach R, Hascall V C, eds. Articular cartilage biochemistry. New York: Raven Press, 1987: 432-40.

22 Roberts S, Weightman B, Urban J, Chappell D. Mechanical and biochemical properties of human articular cartilage from the femoral head after subcapital fracture. $\mathcal{F}$ Bone foint Surg [Br] 1986; 68: 418-22. 